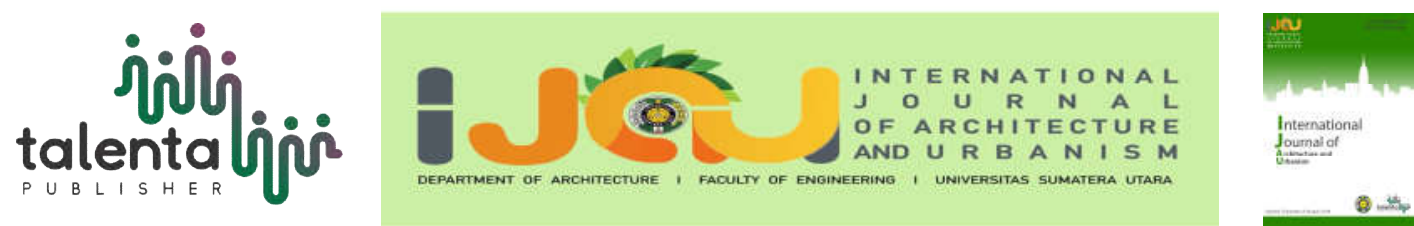

\title{
Designing Mix-Use Waterfront in Kampung Badur
}

\author{
Dwira Nirfalini Aulia ${ }^{1 *}$, Regina Novita ${ }^{1}$ \\ ${ }^{1}$ Department of Architecture, Universitas Sumatera Utara, Medan, Indonesia
}

\begin{abstract}
Currently, the population growth is growing very rapidly resulting in rapid growth of the needs of settlements. The population growth that is not proportional to the availability of land and the income level of the lower middle class resulted in the emergence of illegal settlements and slums and are on land that is inconsistent with the city spatial plan for example on the edge of the river. This condition causes the decreasing quality of life of the people, especially in urban areas, destroying the environment and the spatial arrangement of the city. Medan city is one of the cities that there are many slums. One of the slums in the city of Medan is Kampung Badur located in Hamdan Village Medan Maimun District. The condition of the slums and the low economic level and the location of Kampung Badur located in the city center became the main problem in this area. Therefore, a solution is needed to solve problems in the area by making Kampung Badur an area that provides decent occupancy for occupancy and facilities that could be enjoyed together. The solution to this problem is to re-arrange Kampung Badur and develop potentials in the area. For example, Kampung Badur area which is right on the edge of the river becomes a potential in the design. So that the solution that can be applied is to develop Kampung Badur into Mix-Use Waterfront with a mix-use concept such as residential, public facilities and public open space to be enjoyed by residents Kampung Badur itself and by the people of Medan City.
\end{abstract}

Keyword: mix-used, waterfront, river, slums

\section{Introduction}

Along with the needs of residential space and the population growth, riversides area often becomes settlements because the land is an unused land as it is river border area. It provides an opportunity for low-income people to use the land as a residence due to not spending money to buy it. One of the slums located on the riversides in the Medan is Kampung Badur. Kampung Badur located on the riverside of the Deli River in the urban village of Hamdan and subdistrict of Medan Maimun The location of Kampung Badur still around the center of Medan. Kampung Badur is divided into two areas namely Kampung Badur Atas and Kampung Badur Bawah. The plotting of residential space in Kampung Badur Atas is oriented on Badur street, while in Kampung Badur Bawah on the riversides. The increasing demand for residential space makes

\footnotetext{
*Corresponding author at: Department of Architecture, Faculty of Engineering, Universitas Sumatera Utara, Jalan Perpustakaan Gedung J07, Medan 20155, Indonesia

E-mail address: dwira_aulia@yahoo.com
}

Copyright (C) 2018 Published by Talenta Publisher, Printed ISSN : 2622-0008, online ISSN : 2622-1640

Journal Homepage: https://talenta.usu.ac.id/ijau 
the riversides a target for people to occupy. Thus, the needs are realized by building residential areas in places that should not be built on the riverside.

To overcome the problems that occur in Kampung Badur can be done by rearranging Kampung Badur so that more orderly, feasible, and quality that of course have met the existing standards and regulations of the Government. The condition of the settlements in Kampung Badur itself is very unfeasible, and most people do not want to be eviction so in this design will be rebuilt the settlement for residents in Kampung Badur and also as a place to selling because most of the residents have a profession as a trader. As well as supporting facilities to support people's lives in Kampung Badur such as green open spaces, parks, space for interaction, and children's playground. And also to develop the potential and to maintain the sustainability of the river by applying the Mix-Used Waterfront theme. This selection utilizes the river functions as an area to be enjoyed by the urban community and also provides green open spaces which are very deficient in Medan. With the theme of Mix-Used Waterfront is expected to be a solution or a strategy to solve the problems of slums and squatter settlements in Kampung Badur which located in the riversides.

\section{Literature Review}

As a result of the City Beautiful Movement and the transformation of city's economy from industrial to service during the middle of the 20thcentury [2], many of industrial activities and port facilities in cities centers moved to outside and left vast urban lands especially along waterfronts after the decline of old harbor sites [3]. Waterfront is one of the means and vital container for human from past till present. The area on the water's edge becomes a strategic activity center, crowded and very interested.

A waterfront area is an area which adjacent to water that has physical and visula contacts with sea, lakes, rivers or other bodies of the water. The waterfront is a dynamic area of a city where land and air meet. The point of view of the notion associated with waterfront areas has several meanings. The sea or parts of the city that borders with the water, the port areas, land or an area which adjacent to the waters, especially the part of the cities that faces the sea, river, and lake [1].

Mix-Used is the use of a mix of various land uses or functions within a building [4]. Mix-Used waterfront is being aimed more at merging function of commerce, recreation, housing, offices, transportation, tourism, and sports. The application of this concept is one of the ways to unify the various interests that occur in the development of an urban area. 


\section{Methodology}

In designing a project to be implemented must go through several processes, where the process aims to facilitate the designer in design the building. The process begins with site selection, and in this design, the location is chosen based on the problem of low-density settlements in crowded urban areas, then conducted a review of the literature on urban structures with slum areas in the city of Medan.

The location chosen in this design is Kampung Badur which is a settlement located on the riverside of the Deli River in the urban village of Hamdan and subdistrict of Medan Maimun. The reason for choosing this location is because the design location close to the commercial functions that support the design function, located on a primary highway or a secondary highway, access to design location is not difficult, being near or around the neighborhood.

The orientation of settlements in Kampung Badur is being influenced by the Deli river flow along the area. The location of Kampung Badur which is still in the center of Medan city makes it another portrait of an urban settlement that grows unplanned. After the location selection process is done then the next step is the data collection. The data that has been collected and then analyzed to get a concept.

\section{Result and Discussion}

\section{Space Program}

In designing residential units, an analysis of the population growth of Kampung Badur is being needed. To determine the number of the additional residential unit, then calculate population growth by using the formula Geometric Rate of Growth. For analyzing population growth, here the designer uses two comparisons of data from a population in the subdistrict of Medan Maimun. According to data from Pemko Medan, the total population in Medan Maimun in 2012 amounted to 39,581 people, while in 2015 as many as 40,663 inhabitants. From the percentage of population growth that is $0.8 \%$ for each year, it will be multiplied by the total population of Kampung Badur people. Based on the total number of Kampung Badur's current population of 1037 with 21 families, with an average family, each family member has about five family members. So the calculation of residential units of the village that is the number of population growth 1867 soul divided by the average member of each family then gets 373 units of a dwelling. Where type 36 there are 280 units and 54 there are 93 units.

\section{Analysis of Site Selection}

Kampung Badur located on the riverside of the Deli River in the urban village of Hamdan and subdistrict of Medan Maimun. According to the Development and Development Area of Medan 
City (WPP D) ${ }^{1}$, Kampung Badur is located in the core of the city where its land use functions as $\mathrm{CBD}^{2}$, government center, urban forest, education center, office building, indoor recreation, and settlement. Due to the location of the design that is located in the core of the city and also a slum settlement then this can be a potential in the development and easily reached by the people. The potentials that exist is the location that happens to be on the edge of the river so it can being utilized, and is located in the central area of the city and is in a commercial area, so it becomes a strategic location to be public open space and also a new residential for residents in Kampung Badur. Also, according to $\mathrm{RTRW}^{3}$ of Medan city, the location of this design is also included in the strategic areas of economic growth and strategic of social and cultural fields.

\section{Non-Physical Analysis}

The social life of the residents in Kampung Badur is usually being marked by the interaction that is be done on the terrace of the house or food stalls and snacks and educational studio as a gathering place (Figure 1). While for social activities conducted such as deliberations about life in Kampung Badur, religious events, and independence day event every year (Figure 2). The culture in this village is very diverse. Because of this difference, people can convenient adapt to various people, so they are more open to immigrants. The majority of the tribe is Minang tribe, but there are also people who have Javanese and Batak ethnic. The residents who live are immigrants from other cities who come to the Medan to earn a living and also because there is a family who had first settled. The peoples in Kampung Badur have various jobs; some are traders, laborers or employees. But the majority of people's livelihoods in this village are as traders. Because the economic condition of the citizens mostly as a trader, it can be a potential in this design by providing places for citizens to conduct or open their businesses so it can improve the economy in this village.

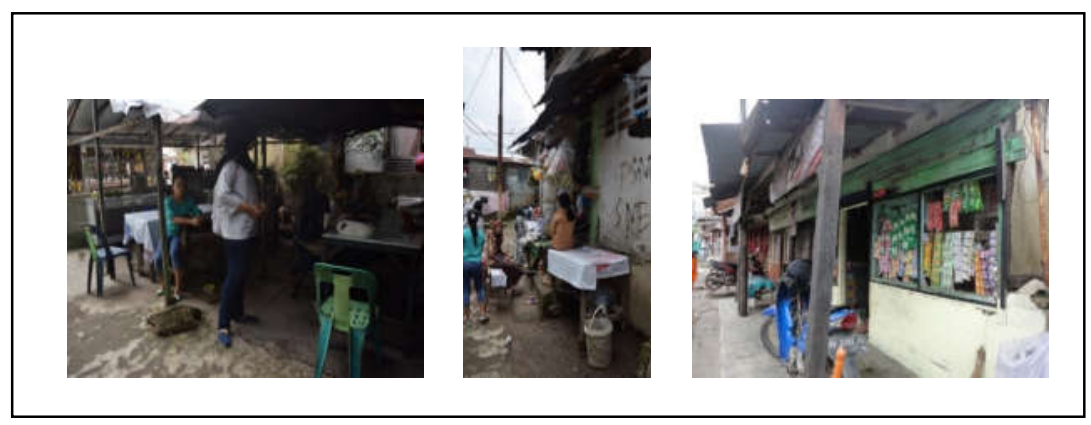

Figure 1. The condition of stalls in Kampung Badur

\footnotetext{
${ }^{1}$ WPP D (Wilayah Pengembangan dan Pembangunan) : Development and Development Area of Medan City

${ }^{2}$ CBD: Central Business District

${ }^{3}$ RTRW (Rencana Tata Ruang Wilayah) : Spatial Plans
} 


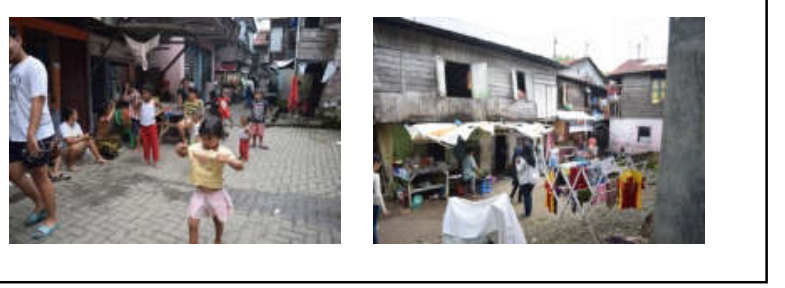

Figure 2. The conditions of social interaction in Kampung Badur

\section{Block Plan Concept}

The block plan concept on Mix-Used Waterfront Design is being divided into three masses with different functions where the core building is a ressidential building, retail store, management office, and mosque (Figure 3). This separation concept supports the mix-used waterfront theme because it prioritizes the space experience for the user. In addition to the building, there are also green open spaces which function a place of recreation or exercise such as a pedestrian, river pedestrian, river theater, fishing pond or play area.

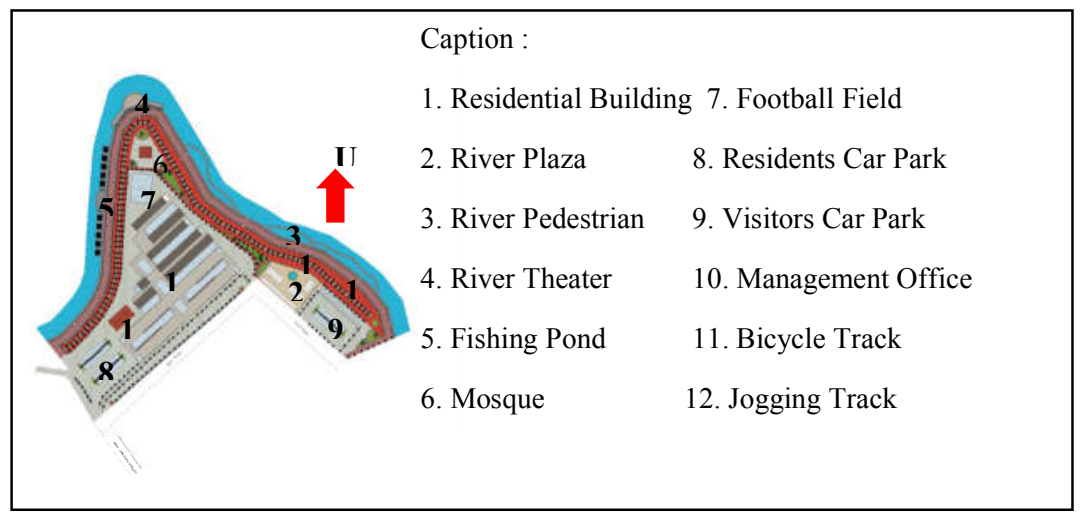

Figure 3. Block plan concept

\section{Designing Outdoor Space/Site}

Zones in this area are being divided into some parts of the zones; there are public, semi-public, private, and service zones (Figure 4). By the applied theme of mix-use waterfront, the concept of this outdoor design consists of several functions that can be enjoyed by the user.

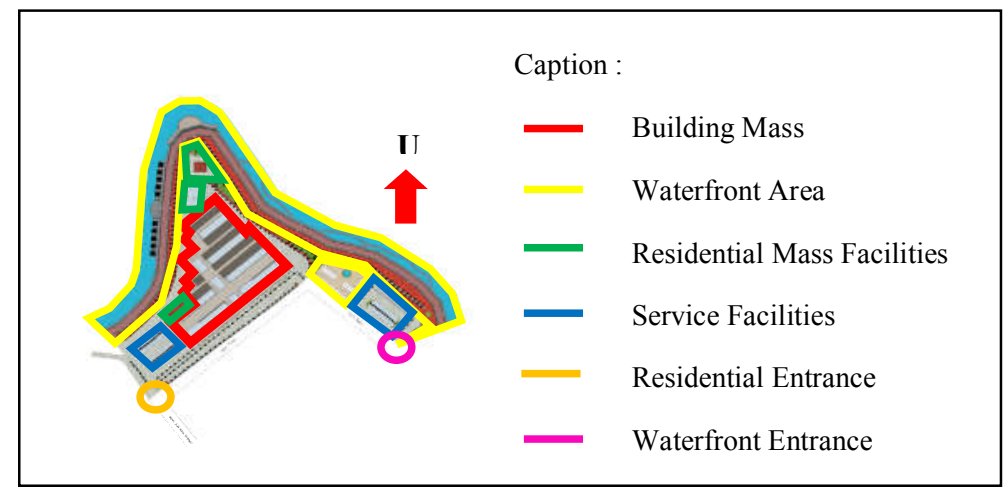

Figure 4. Outdoor space concept 


\section{Circulation}

Circulation on the site is being divided into two parts, that is the circulation of motor vehicles (cars and motorcycles) and pedestrian circulation. The concept of vehicle circulation in this area has planned the entrance to the site access for residents through Imam Bonjol street or Letjen Suprapto street then on Ade Irma Suryani street and from Badur street for visitors. For the motorcycles can be accessed from Imam Bonjol street and Ade Irma Suryani street or Badur street. The same thing happened to cars. While for access out can be passed from Ade Irma Suryani street and Badur street which is a two-way lane (Figure 5). While for the pedestrian circulation will be provided pedestrian paths along with vegetation in the form of shade trees along the road on the tread (Figure 6). The pedestrian will be designed in accordance with existing standards. For the area within the area, pedestrian circulation located around the building, and also on this site will also be designed river pedestrian above the river to get the experience of space water.

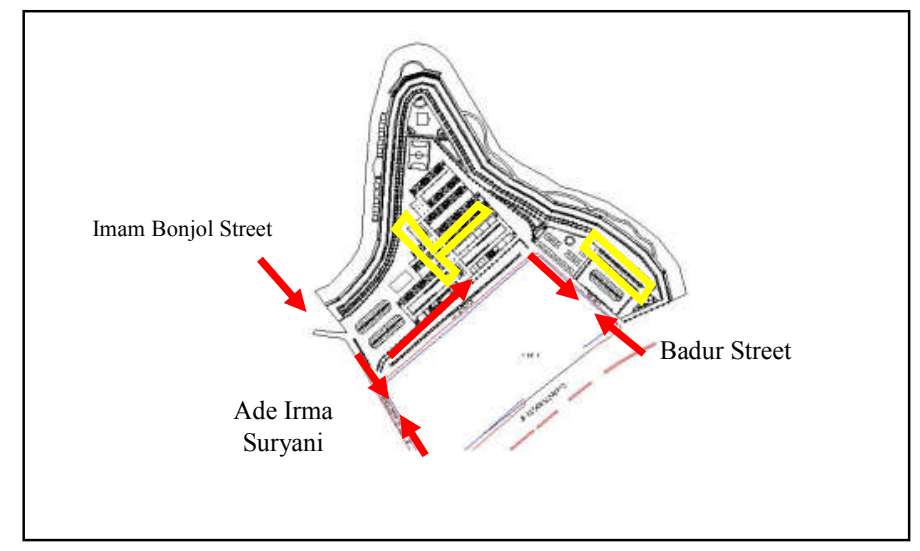

Figure 5. The concept of motor vehicle circulation

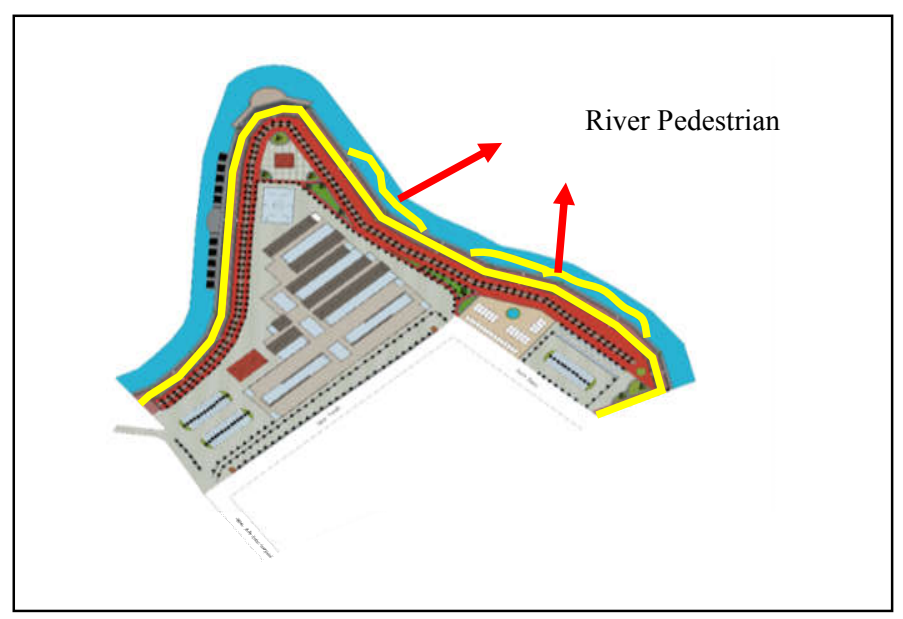

Figure 6. Pedestrian circulation concept 
The service circulation in this design is separate from the public. The circulation on this site divided into two areas that are, service on the dwelling and waterfront service. In the residential area, the service line can be accessed from Saijah street. While on the waterfront service line is located Letjen Suprapto street and the inspection road also available that serves to monitor the function of river service (Figure 7).

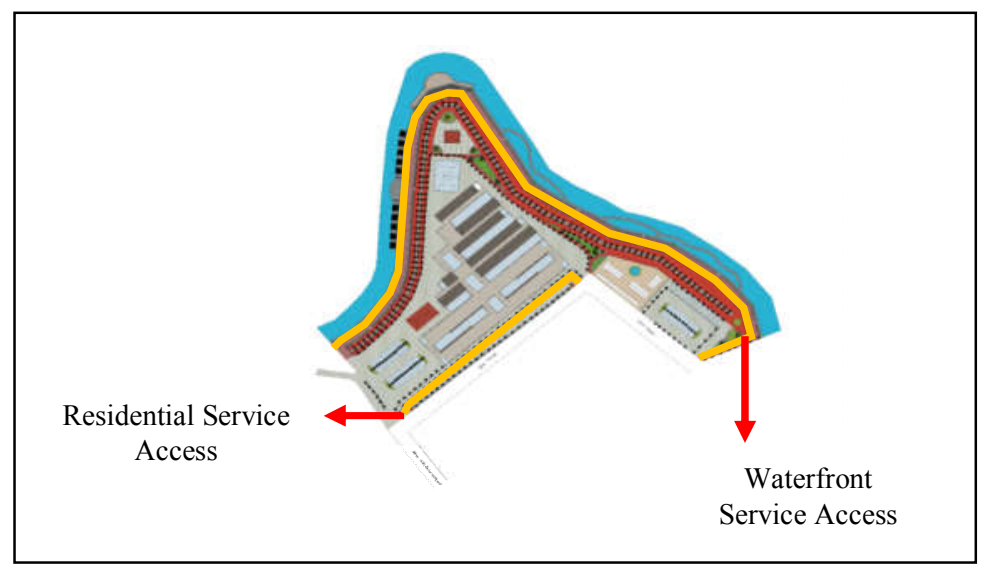

Figure 7. Service circulation concept

\section{Mass Composition}

The concept of planning and display in the building will use materials that are easy to reach and can be recycled. For the wall will be used exposed brick material that is left plain without plaster so it can provide a natural atmosphere. While for the columns and beams also will not be painted. As for the facade of the building will use the recycled woods. And the roof uses metal roof tiles and roof truss using mild steel (Figure 8). The building will be designed with a green concept (green construction or sustainable building) that leads to the structure and use of environmentally responsible and resource-saving processes, from place selection to design, construction, operation, maintenance, renovation and demolition, convenience for building users (Figure 9).

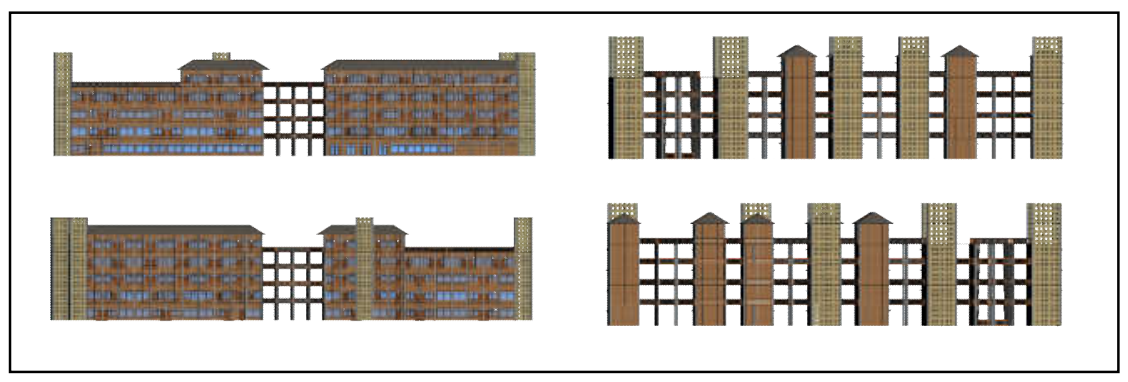

Figure 8. The view of residence 


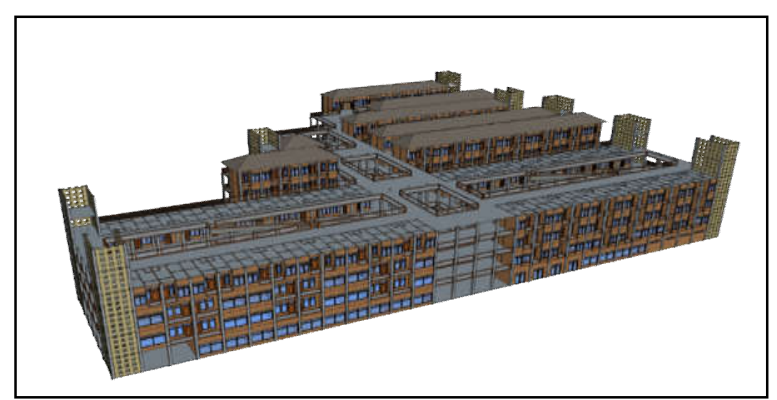

Figure 9. Residence building perspective

\section{Indoor Space}

In this design, there are two residential units that are, type 36 and type 54. The division of residential unit zone based on the economic condition in Kampung Badur. Type 36 occupancy unit is devoted to the head of the unable family while the 54 type residential unit is the head of a capable family. One residential consists of 1 head of household with the number of the family of 4-5 people. The residential building planned with a height of 5 floors. Where the division of this unit itself spreads due to interaction in residence. The indoor space circulation in the residential building uses the corridor with Double Loaded Corridor system and Single Loaded Corridor. This corridor also can be used as a communal space inside the building. In the middle of the dwelling, there is a void that serves as a place of air exchange and natural light.

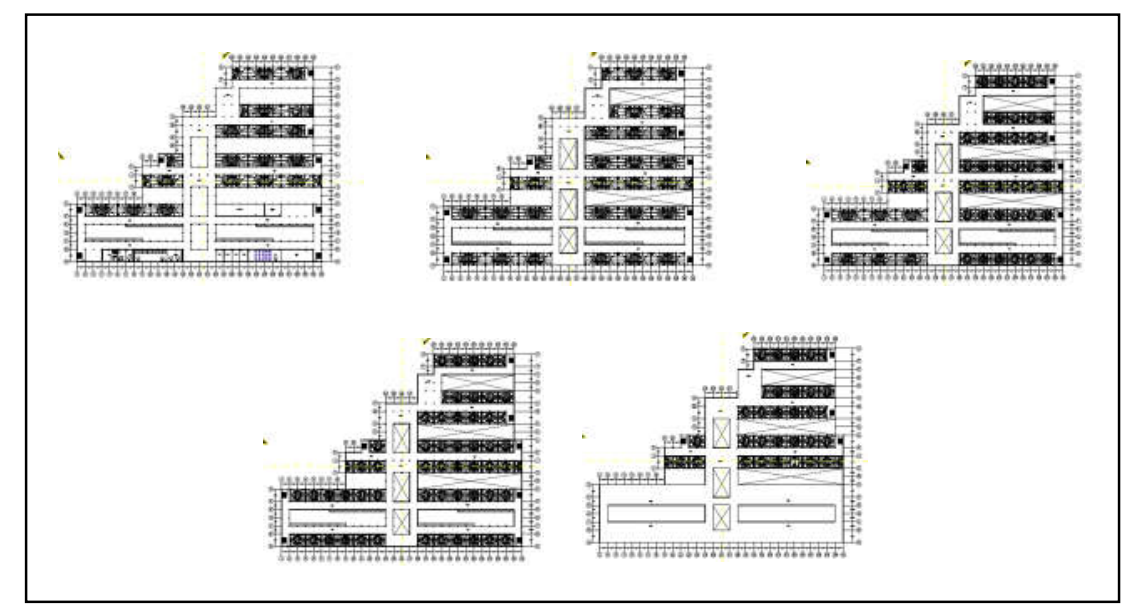

Figure 10. Indoor space concept

\section{Building Structure}

In the main building such as vertical dwelling will use bore pile foundation with reinforced concrete material so it can withstand building load. In the residential building will also using the major beam with the size of 25/50 for the span of 6 meters and the beam of with size 15/20 for span 4 meters and columns with $40 \times 40$ meters. Meanwhile, for other supporting buildings, it will use a stone foundation that is suitable. In this mix-used waterfront design, it also applies the concept of river pedestrian, amphitheater, and fishing pond which located above the river. For 
the structure used in this three facilities is using floating structure (floating structure) with the base of EPS (Expanded Polystyrene). This material has excess durability and does not require maintenance and has a floating factor that is very safe and can transport heavy loads with high capacity. The other advantages of this floating structure are friendly to the environment so it will not damage the river ecosystem.

\section{Conclusion}

The conclusion that can be obtained in this design of Mix-Used Waterfront in Kampung Badur is that the application of this mix-used waterfront is the solution of the settlement of Kampung Badur. This based on the many types of functions residing in Kampung Badur in the form of residential and commercial activities and the lack of open space in the area. So the selection of mix-used will not damage the image of the village itself and also provide comfort for the villagers or the peoples with the waterfront. The reason of this waterfront itself due to the location of the design that is on the edge of the river so that it can become a potential in designing. And also that located around the city center will support this. The focus in this design is to make the mix-used waterfront a place that provides comfort for its users and also contribute to the progress of the city or the village. The selection of this theme is expected to provide many functions to the public and adding new open spaces in the city of Medan which is still very minimal.

\section{Acknowledgment}

This research is part of the requirement to obtain a bachelor's degree in Architecture Department Universitas Sumatera Utara.

\section{REFERENCES}

[1] A. Breen \& D. Rigby. Waterfronts: Cities reclaim their edge. McGraw-Hill Companies. 1994.

[2] G. A. Carlino \& A. Saiz. City Beautiful: Revealed Preferences for Amenities and Urban Growth. Working paper through the Urban Economics Lab. Massachusetts Institute of Technology. 2008.

[3] A. Gospodini. Urban waterfront redevelopment in Greek cities: A framework for redesigning space. Cities,18(5), 285-295. 2001.

[4] D. Procos. Mixed land use: from revival to innovation. Dowden, Hutchinson \& Ross. 1976. 